\title{
Smart Drugs for Smarter Stem Cells: Making SENSe (Sphingolipid-Enhanced Neural Stem Cells) of Ceramide
}

\author{
Erhard Bieberich \\ Program in Developmental Neurobiology, Institute of Molecular Medicine and Genetics, School of Medicine, \\ Medical College of Georgia, Augusta, Ga., USA
}

\section{Key Words}

Ceramide $\cdot$ Neural progenitors $\cdot$ Sphingosine-1-phosphate $\cdot$ FTY720 $\cdot$ Stem cell therapy $\cdot$ Myelination

\begin{abstract}
Ceramide and its derivative sphingosine-1-phosphate (S1P) are important signaling sphingolipids for neural stem cell apoptosis and differentiation. Most recently, our group has shown that novel ceramide analogs can be used to eliminate teratoma (stem cell tumor)-forming cells from a neural stem cell graft. In new studies, we found that S1P promotes survival of specific neural precursor cells that undergo differentiation to cells expressing oligodendroglial markers. Our studies suggest that a combination of novel ceramide and S1P analogs eliminates tumor-forming stem cells and at the same time, triggers oligodendroglial differentiation. This review discusses recent studies on the function of ceramide and S1P for the regulation of apoptosis, differentiation, and polarity in stem cells. We will also discuss results from ongoing studies in our laboratory on the use of sphingolipids in stem cell therapy.

Copyright $\odot 2008$ S. Karger AG, Basel
\end{abstract}

\section{Introduction and Overview}

Ceramide is a membrane-resident sphingolipid and metabolic precursor for sphingosine, sphingosine-1-phosphate (S1P), ceramide-1-phosphate, sphingomyelin, and glycosphingolipids (fig. 1a, b). In addition to being important in stabilizing cellular membranes, sphingolipids have emerged as second-messenger lipids in cell signaling pathways that regulate apoptosis, cell polarity, and differentiation. The ability of sphingolipids to form lipid microdomains or rafts determines their unique role as interface between extracellular growth factors or cytokines, and intracellular cell signaling pathways. Of particular significance is the enzymatic conversion of sphingomyelin to ceramide in the cell membrane, which is triggered by proapoptotic cytokines (fig. 1a). Our group has, for the first time, introduced the hypothesis that ceramide microdomains organize SphingoLipid-Induced Protein Scaffolds (SLIPS) on the inside of the cell [1]. We have provided evidence that SLIPS are initiated by the direct association of ceramide with atypical $\mathrm{PKC} \zeta / \lambda(\mathrm{aPKC})$, a protein kinase $\mathrm{C}$ isoform essential for cell adhesion, polarity, apoptosis, and inflammation $[2,3]$. We hypothesize that the outcome of this association depends on the specific composition of proteins that participate in ceramide-induced

Institute of Molecular Medicine and Genetics

School of Medicine, Medical College of Georgia, 1120 15th Street, Room CB-2803 Augusta, GA 30912 (USA)

Tel. +1 706721 9113, Fax +1 706721 8685, E-Mail ebieberich@mcg.edu 
SLIPS. For example, if cells express high levels of prostate apoptosis response 4 (PAR-4), an inhibitor protein of aPKC, ceramide will induce binding of PAR-4 to aPKC. PAR-4-mediated inhibition of aPKC will then result in apoptosis [2, 4-6]. If cells express low levels of PAR-4, ceramide will promote association of the small GTPase Cdc42 with aPKC and sustain cell polarity [3].

We have proposed to utilize these ceramide-induced protein interactions for the controlled differentiation of embryonic stem (ES) cells [1]. Instead of using water-insoluble ceramide, we have synthesized a novel ceramide analog, $\mathrm{N}$-oleoyl serinol (S18), that is water-soluble, enriches in cellular membranes, and binds to aPKC $[7,8]$. Our group has shown for the first time that S18 can be used to eliminate residual pluriptotent cells from an ES cell-derived neural progenitor or precursor cell (NPC) graft [5]. If contaminated with pluripotent cells teratomas (stem cell tumors) will form after transplantation of NPCs into mouse brain. We have used S18-induced apoptosis of these cells to prevent teratoma formation, an important step toward safer stem cell therapy $[5,9]$.

In new studies, however, we found that a small portion $(<5 \%)$ of useful NPCs express PAR-4. These cells, termed NPC2 cells, are lost after incubation with S18. NPC2 cells express the receptor S1P1 that induces anti-apoptotic cell signaling pathways when activated by binding to S1P $[10$ 14]. Our results suggest that activation of S1P1 by incubation with S1P protects NPC2 cells from S18-induced apoptosis and promotes oligodendroglial differentiation. Accordingly, a combination of S18 and S1P (or the S1P pro-drug analog FTY720) eliminates tumor-forming stem cells and the same time triggers differentiation of NPCs. The present review will discuss the significance of sphingolipids for stem cell differentiation and show recent results from our laboratory on the use of sphingolipids for the design of novel stem cell therapies.

\section{Sphingolipids: An Enigmatic Species of Cell Signaling Lipids}

The term sphingolipids dates back to 1884 when the German pathologist and 'father of neurochemistry' Johann Ludwig Wilhelm Thudichum (1829-1901) first described a class of new lipids derived from the base sphingosine (fig. 1a) [1]. He coined the term 'sphingolipids' (from Greek 'sphingos', genitive of Sphinx), suggesting they were as mysterious as the Sphinx herself. To date, more than one hundred different sphingolipids are known. They are essential components of cellular mem- branes and have been implicated in a variety of biological functions (fig. 1b). Among these, their roles as pro- or anti-apoptotic and pro- or anti-proliferative signaling lipids are the most important. To establish a profile of these functions for individual sphingolipids is difficult because of their rapid metabolic interconversion (fig. 1b).

A major drawback in understanding the function of sphingolipids is that it is mostly not known with which proteins they interact. Binding partners and even specific binding domains have been identified for many other signaling lipids. For example, diacylglycerol, an important pro-proliferative lipid, interacts with the $\mathrm{C} 1$ domain of classical protein kinase $\mathrm{C}(\mathrm{PKC} \alpha)$ and protein kinase D (PKD) [15-19]. Phophoinositols, another class of signaling lipids, bind to the pleckstrin homology $(\mathrm{PH})$ domain $[19,20]$. Once a protein domain of this type has been identified it can be predicted from the amino acid sequence that the protein will bind to the cognate lipid. For sphingolipids, binding partners have only been specified for ceramide $[2,8,21-30]$, ceramide-1-phosphate [31-33], S1P [34-37], and some gangliosides (e.g. GM1). In most cases, it is still not clear which conserved protein domain will interact with a particular sphingolipid.

The 'classical' interaction partners of ceramide are ceramide-activated protein phosphatase(s) $[22,23,38]$ and kinase(s) $[8,24,25,27,28,30,39-43]$. Recent studies have shown that ceramide activation of protein phosphatase 1 (PP1) alters splicing of B-cell lymphoma X (bcl-x) and caspase 9 from anti- to pro-apoptotic proteins [44]. Ceramide-activated protein phosphatase $2 \mathrm{~A}(\mathrm{PP} 2 \mathrm{~A})$ is involved in de-phosphorylation of a variety of key factors in cell signaling pathways regulating proliferation, apoptosis, and differentiation $[22,38,45]$.

Within the group of protein kinases, kinase suppressor of Ras (KSR) [46, 47], PKC $[42,43]$, and aPKC [2, 3, 8, $24-28,45]$ have been found to be activated by ceramide. In the last 10 years, activation of aPKC by ceramide was independently confirmed by several groups [2, 8, 24-28]. A relative of the $\mathrm{C} 1$ domain, the $\mathrm{C} 1 \mathrm{~B}$ domain was identified in the amino acid sequence of PKC $\delta$ and $\mathrm{APKC}$. Because of its structural similarity to diacylglycerol, ceramide has been suggested to bind to this domain [15, 40-42]. It was not until recently, however, that evidence for direct binding of aPKC to ceramide was found $[2,8,24,26,27]$. Our own studies have focused on aPKC based on its affinity to ceramide and novel ceramide analogs $[2,8]$. Ceramide and most likely many ceramide analogs form organized lipid microdomains or rafts in the cell membrane [26, 48-54]. These rafts may allow for repeated and multiple binding (avidity) of ceramide-associated proteins, thereby enhanc- 

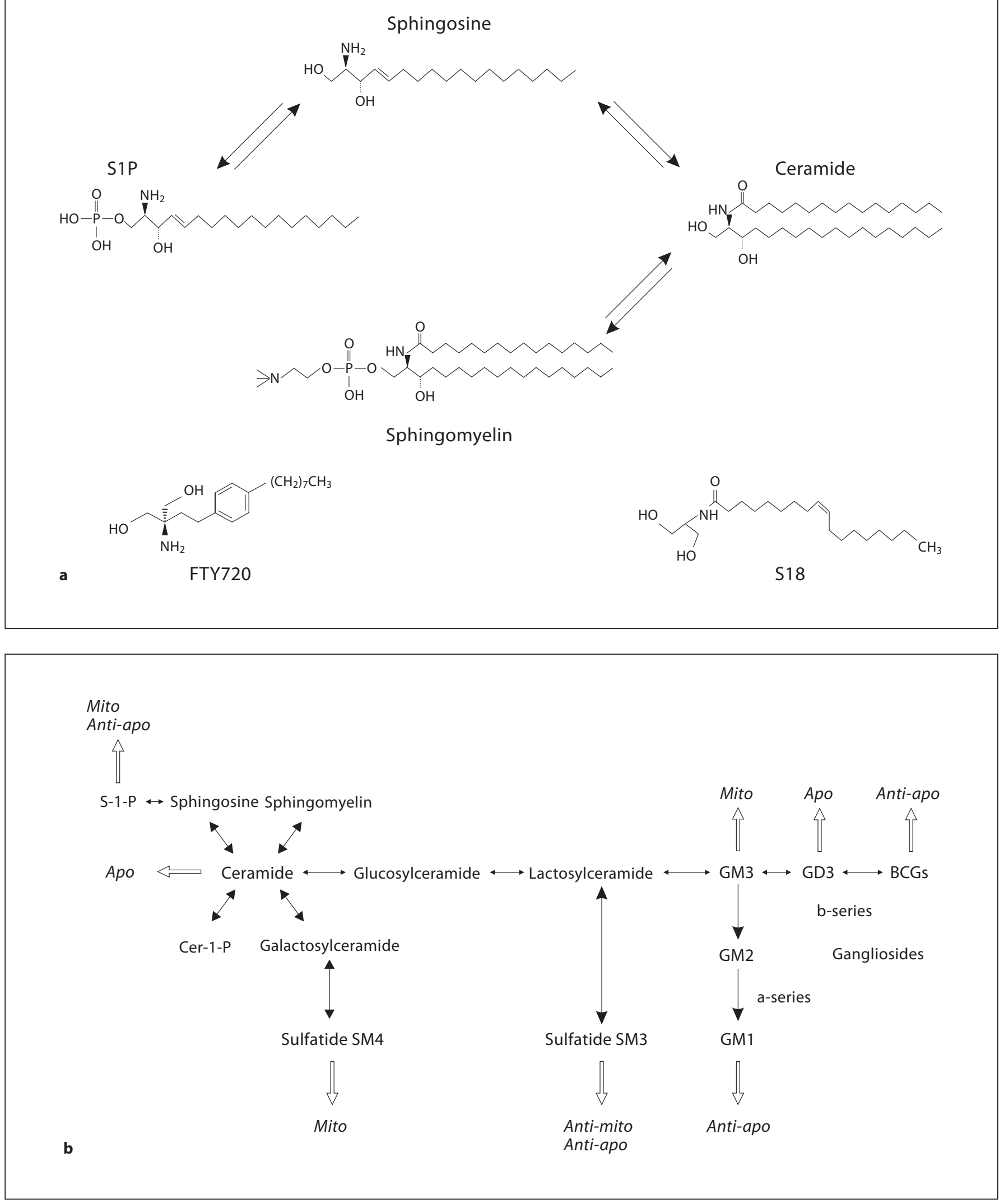
ing the formation of protein complexes with cell signaling functions. Therefore, it is tempting to speculate that ceramide-induced rafts and associated protein complexes form an initial platform for growth factor or cytokine-dependent cell signaling pathways.

\section{Lipid Rafts and SLIPS: A Platform for Cell Signaling Pathways}

Three major cell signaling pathways are regulated by cytokines and growth factors that activate sphingomyelinases, a group of acidic or neutral $\mathrm{pH}$-dependent enzymes that elevate the ceramide concentration in the cell membrane by catalyzing the hydrolysis of sphingomyelin (fig. 1a). Two of these cell signaling pathways, CD95/FasL $[52,53,55-58]$ and TNF $\alpha[30,46,48,59-62]$, are known to induce apoptosis in a variety of cell types by the activation of acid sphingomyelinase (ASMase). In contrast to the cy tokine-activated receptors, the p75NTR cell signaling pathway is not a priori pro-apoptotic. The neurotrophin receptor p75NTR is expressed by many neural cell types and induces axonal outgrowth in the peripheral nervous system when stimulated with nerve growth factor (NGF) [63-67].

However, evidence has amounted that p75NTR-induced apoptosis is a major factor in neurodegenerative diseases such as Alzheimer's disease [68-76]. This apparently paradoxical, dual function of p75NTR, pro-apoptotic or pro-outgrowth, has been explained by a model suggesting that the effect of p75NTR activation depends on heterodimerization with other neurotrophin receptors [77-87]. If p75NTR forms heterodimers with tropomyosin-related kinase A (trkA), a tyrosine kinase receptor, activation of the chimeric receptor induces axonal outgrowth. However, if p75NTR forms homodimers binding of NGF to p75NTR activates neutral sphingomy-

Fig. 1. Metabolism and function of sphingolipids. a Ceramide can be de-acylated by ceramidase to sphingosine. Sphingosine can be phosphorylated to sphingosine-1-phosphate (S1P) by sphingosine kinase (SK) 1 and 2. Ceramide can also be converted to sphingomyelin by sphingomyelin synthase. One important source for ceramide is the hydrolysis of sphingomyelin by acid or neutral sphingomyelinase. The bottom panel shows the structures of the novel ceramide analog S18 (N-oleoyl serinol) and FTY720, a prodrug that is phosphorylated by SK to phospho-FTY720, an analog of S1P. b Structural and functional interconversion of sphingolipids. Mito = Mitogenic; $a p o=$ pro-apoptotic; anti-apo = anti-apoptotic; anti-mito = anti-mitogenic.

Sphingolipid-Enhanced Neural Stem Cells elinase (NSMase), which then generates ceramide and may induce apoptosis.

For a long time, ceramide was stigmatized as being an exclusive inducer of apoptosis. This bias resulted mainly from experiments that used a short chain analog of ceramide, $\mathrm{N}$-acetyl sphingosine (C2 ceramide) to test the induction of apoptosis by ceramide. C2 ceramide is ideally suited as medium supplement because its water solubility is severalfold higher than that of physiological ceramide species (e.g. N-palmitoyl sphingosine or $\mathrm{C} 16 \mathrm{ce}-$ ramide). However, recent advances in administering ceramide with long fatty acid chains and the development of novel ceramide analogs has clearly shown that ceramide has additional, non-apoptotic functions $[2,3,7$, $8,88-92]$. In particular, our group has demonstrated that the pro- or non-apoptotic function of ceramide depends on effectors that modulate the activation of ceramideassociated proteins [2-5].

Ceramide has been shown to form microdomains or rafts within cellular or synthetic membranes $[26,41,48$, $51,54,56,93]$. Lipid rafts are originally characterized by being insoluble in detergent. Using this unique feature to isolate rafts many membrane-resident proteins have been characterized as being raft or non-raft proteins. Unfortunately, it has turned out to be difficult to directly visualize these rafts, which is important to show their biological significance. One of the main reasons for this shortcoming was the unavailability of antibodies against membrane lipids. With respect to ceramide, this has been tremendously improved within the last couple of years $[94,95]$. For example, our group has developed a novel antibody against ceramide that was used to determine the polarized distribution of ceramide in membrane protrusions of neural cells and apical cell membranes of primitive ectoderm cells $[3,95]$.

How would the polarized distribution of ceramide in lipid rafts support its function as second messenger lipid for cell signaling pathways? We have to keep in mind that ceramide is mainly distributed to three compartments of the cell. De novo biosynthesis of ceramide from serine and palmitoyl-CoA takes place in the endoplasmic reticulum (ER) [96-99]. The hydrophobic alkyl chain of sphingosine and the fatty acid residue are buried within the membrane, while the polar head group of the sphingosine (serine) portion faces the cytosol. From the ER, ceramide is transported to the Golgi via ceramide transport protein (CERT) [97, 100]. In the Golgi, ceramide is derivatized by attaching phosphorylcholine or glyosyl groups, which generates sphingomyelin or glycosphingolipids, respectively. At this point, the polar head group has flipped from

Neurosignals 2008;16:124-139 
the cytosolic to the lumenal part of the Golgi. Sphingomyelin and glycosphingolipids are transported to the cell membrane, the polar head group facing the outside of the cell. It becomes clear that any association of ceramide with cytosolic proteins will first require flipping the polar head group back to the inside of the cell.

It should be noted that other compartments, in particular mitochondria, the nucleus, and lysosomes contain ceramide pools as well. Ceramide has been suggested to open a mitochondrial transition pore, which releases proapoptotic proteins such as cytochrome $\mathrm{c}$ and apoptosisinducing factor (AIF) [101, 102]. In the nucleus, ceramide could affect the alternative splicing of RNA encoding proor anti-apoptotic proteins, or cause an imbalance of calcium levels $[103,104]$. The lysosomes are known to generate ceramide via activation of lysosomal ASMase, an enzyme affected in Niemann-Pick disease [105]. Our laboratory has shown that elevation of ceramide in mitochondrial-associated membranes (MAM) of the ER induces a pro-apoptotic aPKC/PAR-4 complex that prevents activation of NF- $\kappa \mathrm{B}$ [2]. However, we have also found that the non-apoptotic functions of ceramide are intimately linked to ceramide localized at the cell membrane.

Figure 2a depicts our working model that shows how the localized and receptor-mediated activation of SMases generates a ceramide raft. It should be noted that ASMase is localized at the outer leaflet, while NSMase is at the inner leaflet of the cell membrane $[56,58,106]$. Accordingly, activation of ASMase generates ceramide first at the outer leaflet, which is followed by flipping of the polar ceramide head group to the inner leaflet of the membrane. In contrast to ASMase, receptor-activated generation of ceramide by NSMase will first require flipping of the polar SM head group to the inner leaflet. Once ceramide is enriched at the inner leaflet, ceramide-binding proteins such as aPKC will initiate a SLIPS, a protein complex proposed by our group for the first time [1]. A SLIPS will promote microtubule formation and as a result, protrusion of the membrane. Depending on the effect of the receptor on SMases (activating or inhibiting), binding of a growth factor or cytokine may enlarge ceramide or SM microdomains, respectively. Intriguingly, studies with synthetic model membranes have shown that ceramide and SM form microdomains that are segregated from each other [50,51, 58, 93]. Hence, receptor activation will polarize the distribution of these two sphingolipids when the ceramide microdomain expands. We should keep in mind that release of ceramide by SMases is an enzymatic process: receptor activation by binding of just one growth factor or cytokine molecule may generate many more ceramide molecules that organize themselves in microdomains or rafts.

Is there experimental evidence for our model? It has been shown that ceramide can rapidly flip from the outside to the inside of the cell membrane [107]. Flipping of SM has been suggested to go in hand with externalization of phosphatidylserine and may involve a phospholipid binding protein termed 'scramblase' or 'flippase' [108111]. Hence, accumulation of ceramide or SM in rafts at the outer membrane leaflet will quickly generate an equivalent microdomain facing the cytosol. There is indirect evidence for this 'inner leaflet' microdomain coming from a recent study showing that the isolated ceramide raft fraction contains aPKC, clearly a ceramideassociated, cytosolic protein [26]. There is also evidence that 'phosphatase and tensin homolog deleted on chromosome ten' (PTEN), another cytosolic protein, is associated with ceramide rafts [112]. This, however, may not involve direct binding of PTEN to ceramide but association with a protein complex organized at the ceramide raft. Better evidence would be provided if we could directly visualize the association of a cytosolic protein with the ceramide raft.

We have used immunocytochemistry for sphingomyelin and ceramide to determine the distribution of these two sphingolipids in the cell membrane of NPCs (fig. 2b). Although sphingomyelin and ceramide domains are in close vicinity to each other, they show only little overlap in their membrane distribution [unpubl. results]. This result is consistent with our model in that ceramide, once generated from sphingomyelin, organizes itself in separate lipid domains. Notably, ceramide is mainly distributed to a perinuclear compartment and the tip of membrane protrusions. These protrusions may represent 'sphingopodia', a term we have introduced when we noticed the polarized distribution of ceramide in microspikes, filipodia and lamellipodia [95]. In previous studies, we have used fluorescence resonance energy transfer (FRET) to confirm the direct association of ceramide with aPKC in the ceramide-rich perinuclear compartment [2]. FRET is a technique that utilizes the direct, radiation-free energy transfer from one fluorophore to another one when they are close together $(<10 \mathrm{~nm})$. Figure $2 \mathrm{c}$ shows initial studies obtaining a Cy3-to-Cy5 FRET signal from $\alpha$-tubulin (bound to Cy3-conjugated antibody) to ceramide (bound to Cy5-conjugated antibody) in membrane protrusions of NPCs. In summary, our studies support the model shown in figure $2 \mathrm{a}$ in that one of the non-apoptotic functions of ceramide may be the regulation of cell polarity and assembly of microtubules. 


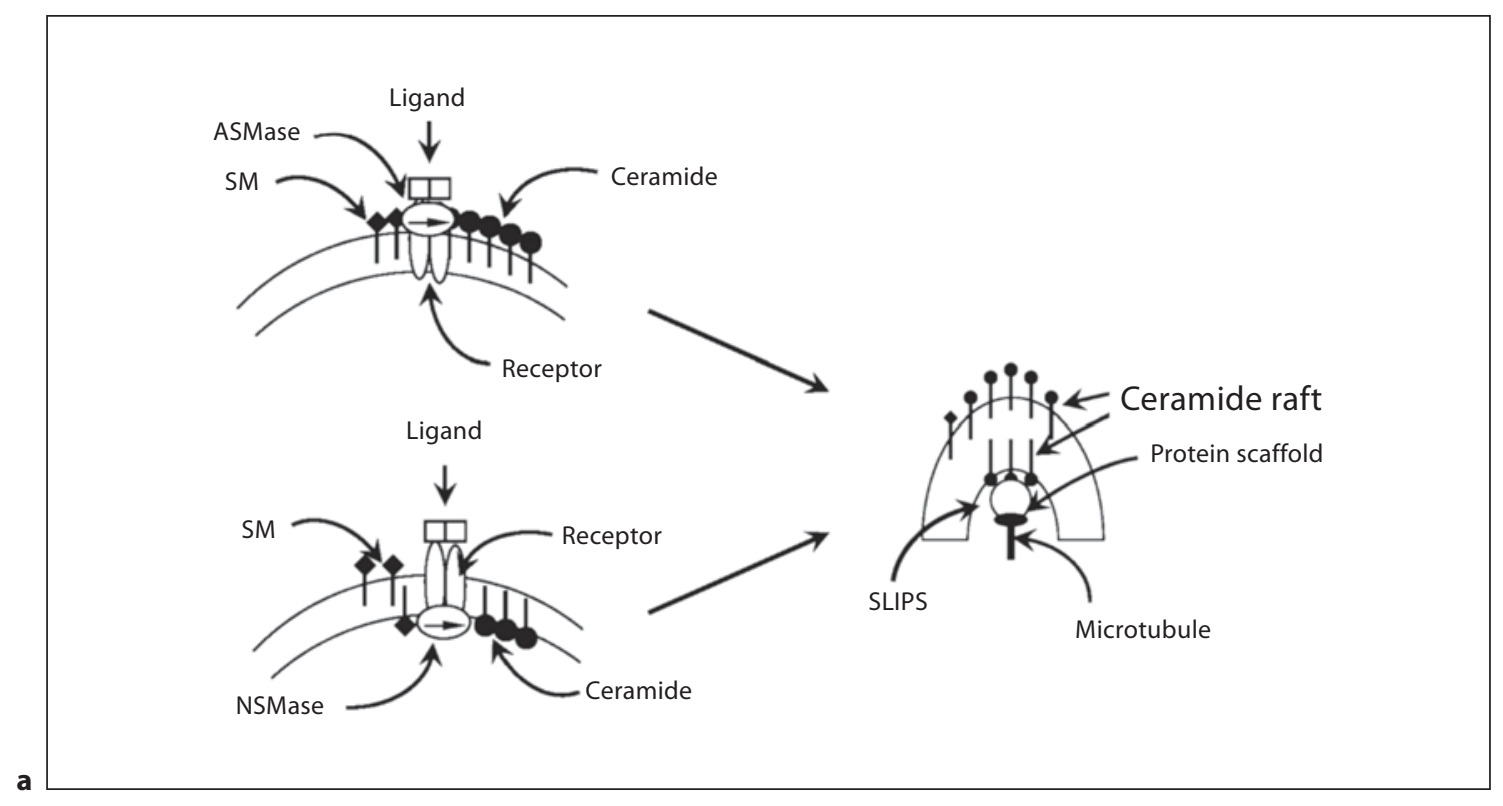

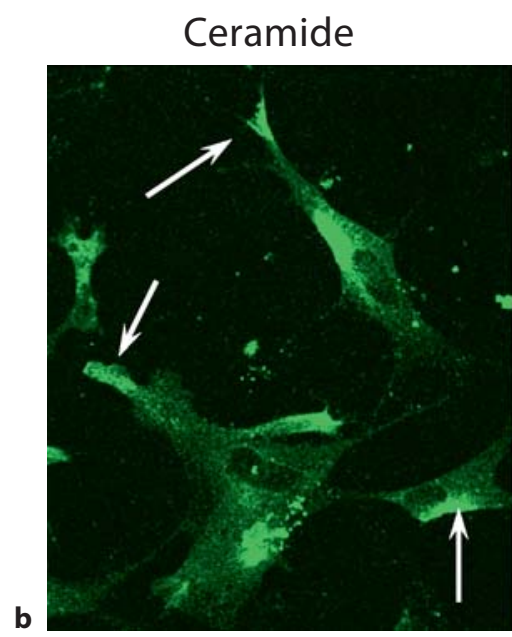

Ceramide

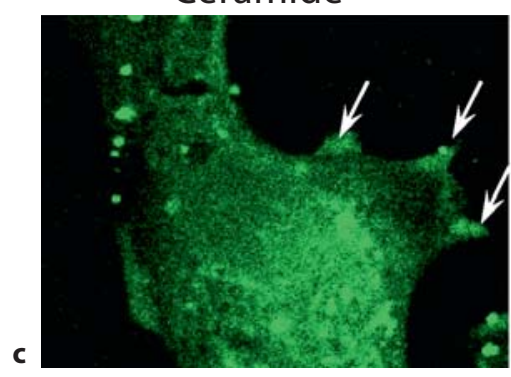

Fig. 2. From rafts to SLIPS. a Model for the formation of ceramide rafts by cytokine or growth factor-activated acid or neutral sphingomyelinase (A or NSMase). A ceramide-associated protein complex (sphingolipid-induced protein scaffold or SLIPS) is formed at the inner leaflet of the cell membrane. This may organize cell adhesion or microtubule assembly and protrude the raft on the tip of a growing process. b Experimental evidence for ceramide rafts and SLIPS in NPCs. Immunocytochemistry for ceramide and

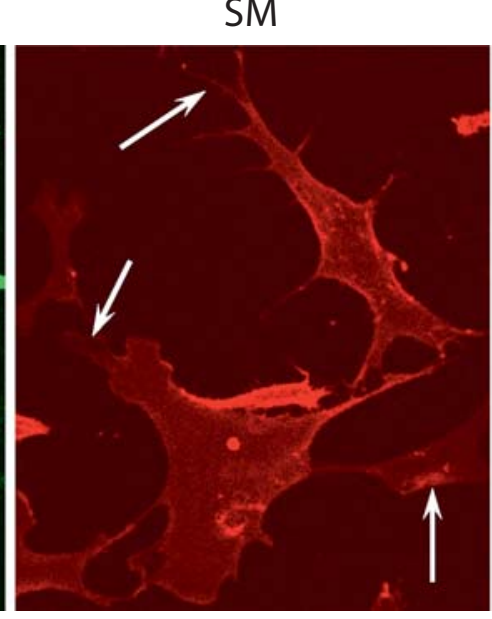

Tubulin

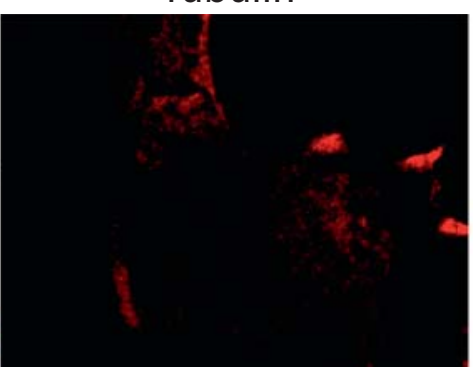

Overlay

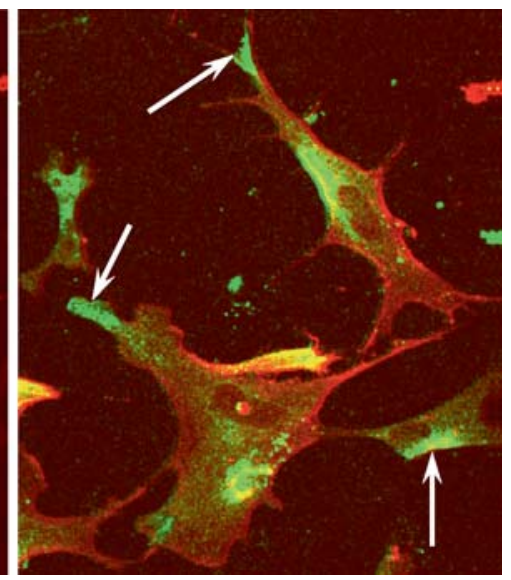

FRET

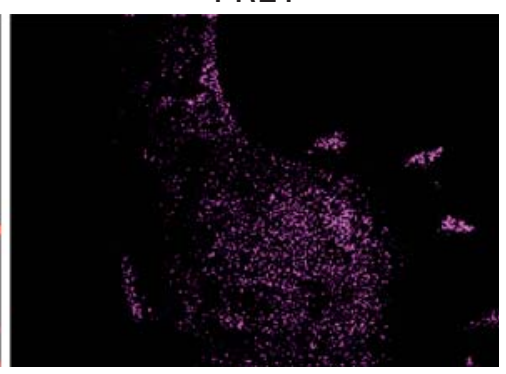

sphingomyelin. Ceramide microdomains at the tip of the cell (arrows) are mostly segregated from SM domains. c Immunocytochemistry for ceramide (Cy5-conjugated) and $\alpha$-tubulin (Cy3conjugated, after 2nd fixation and permeabilization). Cy3 ( $\alpha$-tubulin)-to-Cy5 (ceramide) FRET was recorded indicating that ceramide and nascent microtubules form a complex (arrows). The FRET signal was confirmed by acceptor bleaching as described in Wang et al. [2] (not shown). 


\section{Ceramide and S1P: Key Regulators of Stem Cell Polarity and Apoptosis}

In the previous section, we have discussed a potential non-apoptotic function of ceramide. We will now discuss the mechanism underlying this function and how it is regulated. Our studies have shown that the non-apoptotic function(s) of ceramide depend on a low expression level of PAR-4, a protein that inhibits ceramideassociated aPKC. We have found that there are three stages during ES cell differentiation at which expression of PAR-4 is absent or low: undifferentiated ES cells, suspension EBs, and NPCs [2-5, 113]. Recently, we have reported that in suspension EBs, ceramide is essential for the polarity of primitive ectoderm cells [3]. Ceramide depletion prevents membrane association of aPKC, disrupts the interaction between $\mathrm{aPKC}$ and $\mathrm{Cdc} 42$, and results in decreased phosphorylation of GSK-3 $\beta$. The novel ceramide analog S18 restores primitive ectoderm formation, indicating that it is ceramide and not one of its derivatives that regulates cell polarity. Although this suggests a regulatory effect of ceramide on the noncanonical Wnt or cell polarity pathway, further studies are needed to clarify the significance of ceramide for cell polarity in a wider spectrum of cells.

We propose the working model shown in figure $3 \mathrm{a}$ to explain the function of ceramide for cell polarity in NPCs and other cell types. Based on our observation that ceramide microdomains co-distribute or even associate with microtubules (fig. 2a, c) [1,95], we focus on the effect of ceramide-associated aPKC on GSK- $3 \beta$. GSK- $3 \beta$ phosphorylates many proteins that regulate cell adhesion or formation of microtubules. Key factors are $\beta$-catenin, adenomatous poliposis coli (APC), and $\tau$-protein [114-122]. Phosphorylation of $\beta$-catenin by GSK-3 $\beta$ renders it susceptible to proteolytic degradation [116], while hyperphosphorylation of $\tau$ causes its aggregation in tauopathy, a neurodegenerative disorder that is also involved in the etiology of Alzheimer's disease [114, 119, 120]. Phosphorylation of APC by GSK-3 $\beta$ disrupts its function in stabilizing the plus end of microtubules [116]. According to our model, ceramide-induced activation of aPKC will result in aPKC-dependent phosphorylation and/or inactivation of GSK-3 $\beta$. Hence, ceramide and S18 should stabilize microtubules, while ceramide depletion will destabilize them (fig. 3a).

Figure $3 \mathrm{c}$ shows that among the factors that regulate adherens junctions and microtubules, ceramide-activated aPKC and PP2a may complement each other. It is known that PP2a dephosphorylates $\beta$-catenin, APC, and $\tau[115,120]$. Hence, loss of phosphorylation by ceramidemediated inactivation of GSK-3 $\beta$ (via ceramide-activated aPKC) and enhanced dephosphorylation by ceramideactivated PP2a should act synergistically on promoting the stability of microtubules. Interestingly, GSK-3 $\beta$ can also phosphorylate and inactivate PP2a [123]. Therefore, ceramide can activate PP2a in two ways: by direct binding to PP $2 a$ and by inactivating GSK-3 $\beta$. In contrast to this, ceramide-activated PP2a may also dephosphorylate GSK- $3 \beta$, thereby antagonizing inactivation of GSK-3 $\beta$ by ceramide-activated aPKC [124]. Clearly, more studies on the ceramide-dependent interplay of aPKC, GSK-3 $\beta$, and PP2a are needed to unravel these intricate regulatory mechanisms.

PAR-4 is a leucine zipper protein with several functions. It was discovered by differential hybridization to identify pro-apoptotic genes expressed in androgen-dependent prostate cells [125]. Using two hybrid assays it was soon found to be an inhibitor of aPKC and transcriptional co-repressor of Wilms' tumor suppressor 1 (WT1) $[126,127]$. Recently, PAR-4 has gained attention due to its multifaceted function in neural cells. It has been suggested to contribute to neurodegeneration in Alzheimer's and Parkinson's disease, and to the etiology of amyotrophic lateral sclerosis and stroke [86, 128-132]. In addition to its pro-apoptotic functions, PAR- 4 has been shown to regulate the activity of choline acetyl transferase, to inhibit choline uptake, and to regulate synaptic plasticity [133-135]. In this regard, it may be of interest that PAR-4 has been found to be temporarily associated with the actin cytoskeleton [136]. Our group has described a short form of PAR-4 that acts as dominant negative regulator of apoptosis by forming actin-associated heterodimers with the pro-apoptotic long form of PAR-4 [6].

When the pro-apoptotic form of PAR- 4 is expressed, the non-apoptotic effect of ceramide changes fundamentally. Using lipid vesicles made of ceramide and phospholipids (termed LIpid vesicle-Mediated Affinity Chromatography or LIMAC) we have found that association of aPKC with ceramide will enhance the affinity of aPKC to its inhibitor PAR-4 [2]. In the presence of PAR-4, ceramide will not activate aPKC, but on the contrary, enhance its inhibition by PAR-4 (fig. $3 \mathrm{~b}$ ). Because of this, an initial non-apoptotic or even pro-survival function of ceramide can rapidly turn into the induction of apoptosis.

In addition to its immediate cell signaling function, ceramide serves as metabolic precursor for another important cell signaling lipid, sphingosine-1-phosphate (S1P). Ceramide is hydrolyzed by ceramidase to sphingo- 
Fig. 3. Molecular interactions of ceramideassociated aPKC (working models). a In the absence of PAR-4, ceramide-associated aPKC forms a polarity complex with Par3, Par6, and Cdc42. This may control microtubule assembly and protrude the cell membrane. $\mathbf{b}$ In the presence of PAR4, ceramide-associated aPKC binds to PAR-4, which inhibits its activity and induces apoptosis. c Ceramide activates distinct cell signaling pathways depending on the expression level of PAR-4. In PAR-4(-) cells (left panel), ceramide activates aPKC, which inactivates GSK-3 $\beta$ and stabilizes $\beta$-catenin, increases binding of APC to the plus ends of microtubules, and prevents aggregation of $\tau$. Ceramide-activated PP $2 \mathrm{a}$ may complement this effect on aPKC. In PAR-4(+) cells, ceramide induces inhibition of aPKC by PAR-4, which inactivates NF- $\kappa \mathrm{B}$ and PI3K/Akt, two key cell signaling pathways for cell survival. Inhibition of Akt prevents inactivation of $\mathrm{Bad} / \mathrm{Bax}$ and induces apoptosis. This is antagonized by S1P-mediated activation of Akt.
In the absence of PAR-4: ceramide promotes cell polarity

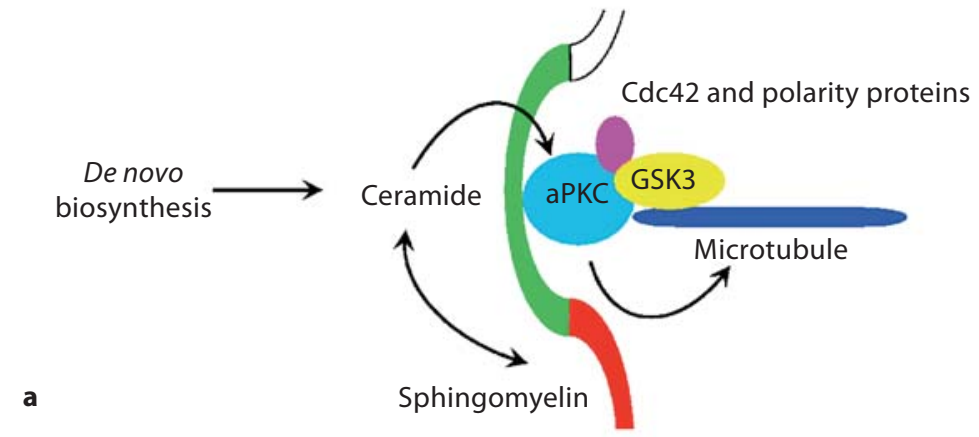

In the presence of PAR-4: ceramide induces apoptosis

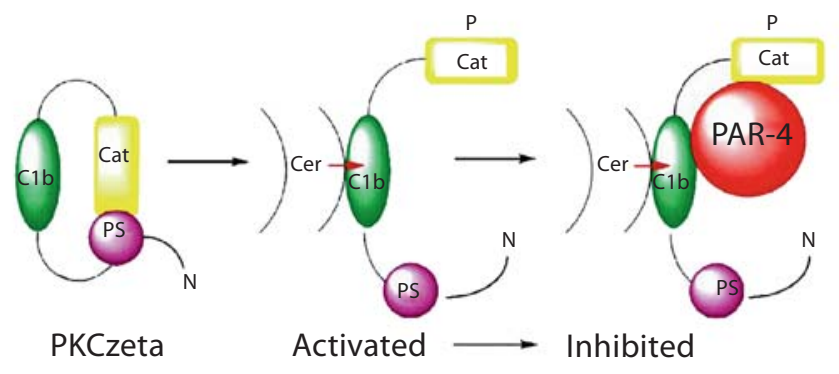

b

PAR-4(-) cells

PAR-4(+) cells
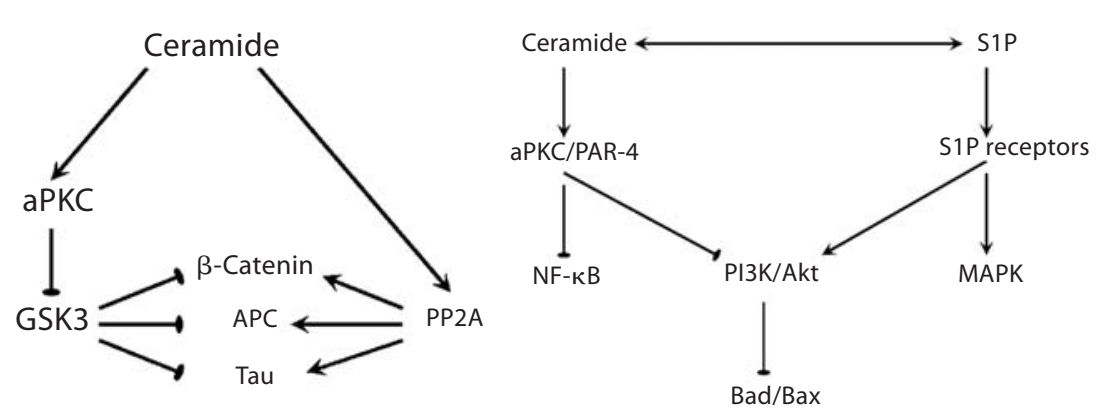

c sine, which is then phosphorylated by sphingosine kinase 1 or 2 (SK1 or 2) to S1P (fig. 1a) [137-144]. S1P is a soluble ligand that can bind and activate five isoforms of the S1P receptor [21, 34-36, 39, 145-147]. Knockout mice for SK1 and 2 or S1P receptors have clearly demonstrated the essential function of S1P for vascular and neural development [138]. Recent studies indicate that one of the functions of S1P is to counterbalance ceramide-induced apoptosis $[88,141,148]$. S1P is known to increase phosphorylation of p42/44-MAPK and Akt (protein kinase B), two important protein kinases that inactivate the pro- apoptotic proteins Bad and Bax (fig. 3c) [1, 113, 145, 149155]. Unlike S1P, ceramide has been shown to reduce the activity of p42/44-MAPK and Akt $[26,113,154,156]$. Hence, it is tempting to speculate that ceramide and S1P counterregulate the phosphorylation of Bax and Bad, thereby controlling apoptosis and cell survival (fig. 3d).

At this point, it is useful to summarize sphingolipidregulated cell signaling pathways that allow for a predictive outcome of ceramide and S1P elevation on cell polarity and apoptosis based on the expression profile of receptor and modulator proteins: 
- If p75NTR, but not trks are expressed, neurotrophins will reduce sphingomyelin and increase ceramide levels.

- If PAR-4 is expressed, ceramide induces apoptosis. If PAR-4 is not expressed, ceramide does not induce apoptosis, but may promote cell polarity or differentiation.

- If S1P receptors are expressed, S1P will counteract ceramide-induced apoptosis and promote differentiation.

In the following sections, we will discuss how this profiling identifies neural stem cells that respond to ceramide and S1P in a predictable fashion. We will also show first results from our laboratory, which utilize this profiling to purify a particular population of stem cells.

\section{Pluripotency Factors and Stem Cell Derived-Tumors: Active Elimination of Risky Stem Cells with Novel Ceramide Analogs}

One of the major perils using stem cells for therapy is their ability to maintain or (re-)adopt a pluripotent state that endows them with the capacity of forming teratomas (stem cell-derived tumors). Teratoma formation has been reported in roughly half of the studies using embryonic stem (ES) cell-derived stem cell grafts [5, 9, 157-167]. The risk is inversely proportional to the differentiation stage. The more differentiated the stem cells, the lower the probability of teratoma formation. However, even genetically re-programmed adult cells, regardless of initially being stem cells or differentiated cells, form teratomas if endowed with pluripotency factors [168]. Therefore, techniques are needed to prevent teratoma formation from stem cell transplants.

Teratoma formation from ES cells can be avoided by differentiating these cells to a particular progenitor stage that allows for repeated self-renewing of the progenitor cells. Continuous passaging of neural progenitors will eventually 'dilute out' pluripotent cells and minimize the risk of teratomas. However, in stem cell therapy, size matters. In experiments with mice, the number of transplanted cells is usually in the range of $10^{5}-10^{6}$ cells/injection. This number is pre-determined by the injection technique: the small volume of the cell suspension does simply not accommodate a larger number of cells if a single dose is injected. A human brain, however, is 1,000-times larger than a mouse brain. It is questionable that this low number of cells will be able to repair tissue, in particular, if it is not desired that the cells retain the capacity of re- peated cell division after transplantation. Our studies have shown that within a population of embryoid bodyderived cells at the stage of generating NPCs, up to $30 \%$ of the cells may retain pluripotency and therefore pose a serious risk of teratoma formation [5]. In terms of risk/ benefit assessment of stem cell therapy, a simple rule may work against us: the number of injected cells will need to be proportional to the size of damage, while it takes just one cell to form a tumor.

Stem cell therapy without techniques actively eliminating teratoma-forming cells may only be successful if combined with genetic engineering of the transplanted cells. Fluorescent or surface proteins expressed under the control of a progenitor-specific promoter (e.g. nestin, Sox-1, Olig-2) have been used to 'purify' NPCs or oligodendrocyte precursors by fluorescence- or magnetic-activated cell sorting (FACS or MACS) and to rid them of residual pluripotent cells [169-172]. Conversely, fluorescent protein expression under the control of the Oct-4 promoter can be used to remove pluripotent stem cells or to confirm loss of pluripotency in the graft. However, these methods will need stable transfection with a transgene that will be present in the graft, regardless of the gene product being expressed or not. While certainly feasible for animal studies, it will add another layer of intricacy for approval in human stem cell therapy.

Alternatively, residual pluripotent stem cells can be eliminated by harnessing an intrinsic sensitivity toward apoptosis inducers. We have shown for the first time that these cells co-express the pluripotency marker Oct- 4 and the apoptosis sensitizer PAR-4 [5]. As discussed in the previous sections, PAR- 4 is an inhibitor protein that binds to aPKC when associated with ceramide. Inhibition of aPKC induces apoptosis. Hence, simply incubating differentiating ES cells at the stage of forming NPCs with the novel ceramide analog S18 eliminates Oct-4(+) cells because they are sensitized to ceramide due to the co-expression of PAR-4. Our studies have shown that this technique can be used to prevent teratoma formation when transplanting neural stem cells derived from ES cells [5].

Active elimination of teratoma-forming stem cells from a graft using novel ceramide analogs was possible because we determined the protein expression profile, in particular pluripotency and sensitivity to apoptosis inducers, in these cells. However, in ongoing studies, we discovered that a small portion of useful NPCs may also be sensitive toward ceramide because they express PAR4. Profiling for factors that allow for protection against ceramide will form a rationale to use additional drugs to protect these ceramide-sensitive cells. 


\section{Making SENSe of Sphingolipids: Design of Sphingolipid-Enhanced Neural Stem Cells}

The in vitro differentiation protocol used in our group follows McKay's original procedure of inducing neural differentiation by serum deprivation of ES cells $[4,5,173$, 174]. Fibroblast-free ES cells are first cultivated as suspension embryoid bodies (EBs) and then as attached EBs. Attached EBs are dissociated and re-plated in serum-free medium in the presence of basic fibroblast growth factor. This protocol consistently yields a homogenous population of NPCs that are self-renewing and express wellcharacterized markers such as Sox1 and nestin. ES cellderived NPCs can be further differentiated to neurons and glial cells in vitro and in vivo after transplantation into mouse brain.

We have shown that ceramide is elevated in in vitro differentiating ES cells and that it is essential for the morphogenesis of the primitive ectoderm layer at the stage of suspension EBs [2-4, 113]. However, the role of ceramide changes dramatically as soon as suspension EBs have attached. The expression of PAR- 4 is up-regulated and renders the differentiating ES cells susceptible to ceramideinducible apoptosis. Depending on the expression level of ceramide and PAR-4, cells will differentiate to NPCs concurrent with up-regulation of nestin (PAR-4(-) cells), or they will undergo apoptosis (PAR-4(+) cells). We have shown that asymmetric cell division will result in the distribution of PAR-4 to one and nestin to the other daughter cell [4]. The daughter cell that inherits PAR-4 can be eliminated by supplementing the medium with ceramide or novel ceramide analogs, while the nestin expressing daughter cell can be used for stem cell transplantation. As discussed in the previous section, we have used this technique to rid a neural progenitor graft of residual pluripotent, teratoma-forming stem cells.

In further studies, however, we have found that a small subpopulation $(<5 \%)$ of NPCs express low levels of nestin and high levels of PAR-4. Because the characterization of these cells is still a matter of ongoing research in our laboratory, we have termed the nestin(low)/PAR-4(+) cells neural precursor cells 2 (NPC2) as opposed to NPC1, the 'classical' nestin (high)/PAR-4(-) neural progenitors. Unfortunately, NPC2 cells are eliminated by incubation with S18 due to the expression of PAR-4. In an attempt to protect these cells from ceramide- or ceramide analoginduced apoptosis, we determined the expression profile of cell signaling pathways that counteract ceramide by promoting cell survival.

Sphingolipid-Enhanced Neural Stem Cells
In a preceding section, we have discussed that $\mathrm{S} 1 \mathrm{P}$ is a natural antagonist of ceramide-inducible apoptosis (fig. 3c). We determined the expression profile for S1P receptors to test whether S1P can rescue NPC2 cells from S18-induced apoptosis. NPC2 cells, but not residual pluripotent $(\mathrm{Oct}-4(+))$ cells express the S1P receptor S1P1 (fig. 4a) [unpubl. results]. Consistent with this expression, S1P or its analog FTY720 protects NPC2 cells from S18-inducible apoptosis, which increases their number by fourfold. Accordingly, the combined administration of S18 and FTY720 eliminates teratoma-forming cells (Oct$4(+) /$ PAR-4(+)/S1P1(-)) as well as it promotes survival of NPC2 cells (Oct-4(-)/PAR-4(+)/S1P1(+)) (fig. 4b). In addition to S1P1, NPC2 cells express the oligodendrocyte precursor markers A2B5 epitope (fig. 4c) and NG2 proteoglycan. Thus, they may be similar (or even identical) to ES cell-derived oligodendrocyte precursor cells described in other studies [172, 175-182]. We are currently investigating the differentiation potential and use of NPC2 cells for stem cell therapy.

\section{Concluding Remarks}

Studies in our laboratory have shown that profiling of pro-apoptotic or pro-survival factors can guide the design of novel protocols for stem cell differentiation. To our knowledge, this is the first time that profiling of cellsignaling factors responding to sphingolipids has been used to design stem cell differentiation protocols. Figure $4 \mathrm{~b}$ summarizes our results and their significance for stem cell therapy. The first profile to be determined is that of pluripotency factors such as Oct- 4 . If Oct- 4 is expressed cells are at risk to form teratomas. We have found that Oct- 4 is co-expressed with the apoptosis sensitizer PAR$4[4,5]$. Hence, ceramide analogs such as $S 18$ can be used to eliminate teratoma-forming cells. However, characterizing a profile of pro-apoptotic proteins such as PAR-4 may show that other, Oct-4(-) cells are also sensitive toward apoptosis. Hence, it will be necessary to determine a profile of anti-apoptotic, pro-survival factors that can be used to rescue Oct-4(-)/PAR-4(+) cells. We found that expression of S1P1 on NPC2 cells is such a factor. Accordingly, we use S1P or FTY720 to rescue these cells from ceramide or S18-induced apoptosis. Of course, this protocol only works if risk factor-expressing cells (e.g. teratoma-forming stem cells) do not express S1P receptors, the activation of which would antagonize S18-induced apoptosis. 


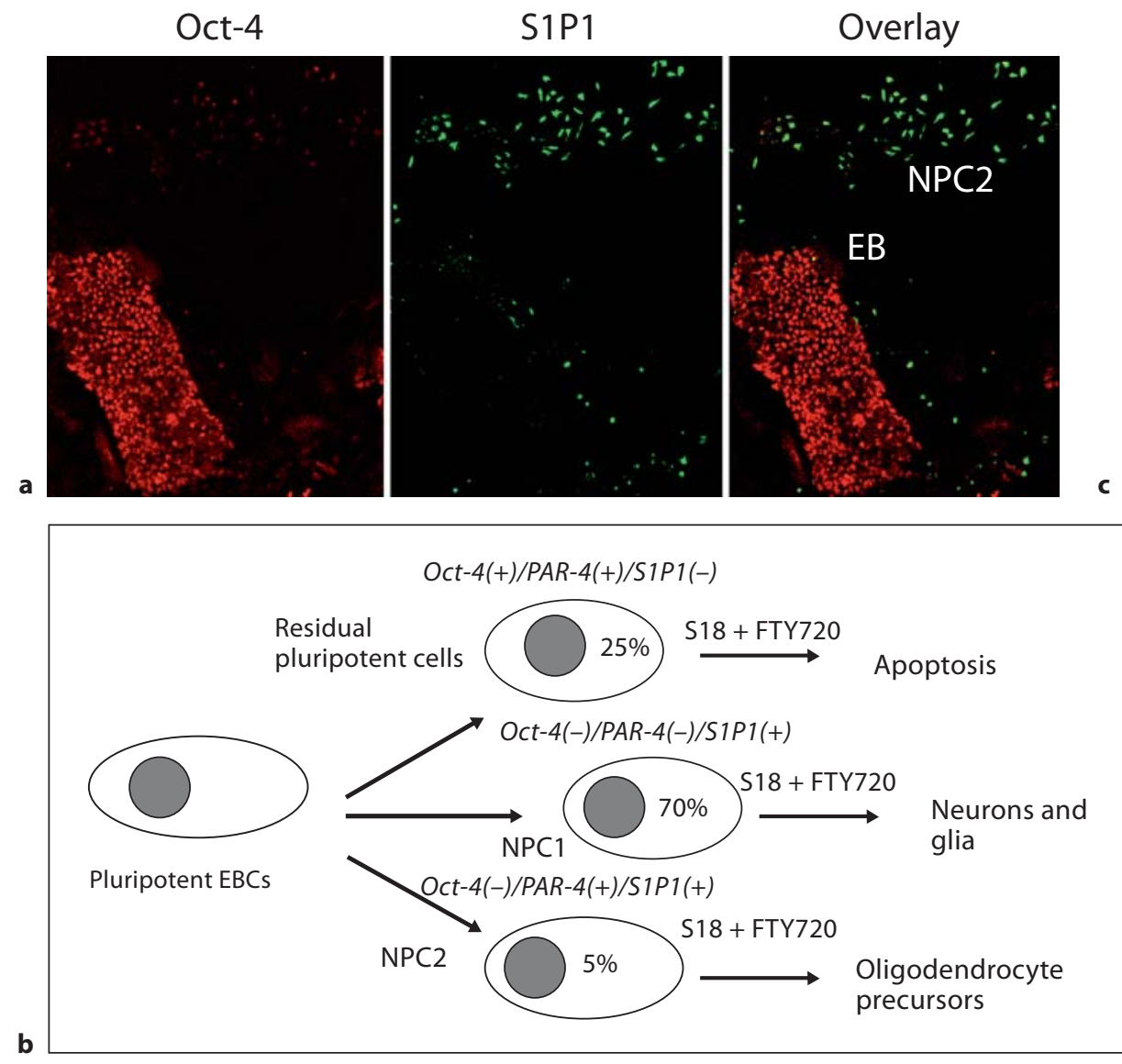

Fig. 4. Making SENSe. a Mouse ES cells were differentiated to the attached EB stage and immunocytochemistry performed using antibodies against Oct- 4 and S1P1. NPC2 cells are Oct-4(-) and $\mathrm{S} 1 \mathrm{P} 1(+)$. b There are three subpopulations of EB-derived cells (EBCs): (1) Residual pluripotent (Oct-4(+)/PAR-4(+)/S1P1(-) cells. These cells form teratomas, but are eliminated by $S 18$ because they express the sensitizer protein PAR-4. They are not protected by $\mathrm{S} 1 \mathrm{P} 1$ (however, the expression of other S1P receptors has not been tested yet). (2) NPC1 cells are Oct-4(-)/PAR-4(-)/S1P1(+) and represent nestin-expressing neural progenitors. They do not undergo S18-induced apoptosis because they do not express PAR-4. (3) Oct-4(-)/PAR-4(+)/S1P1(+) NPC2 cells, however, are eliminated by $\mathrm{S} 18$, but they can be protected by incubation with S1P or FTY720. c NPC2 cells are stained for A2B5 epitope (lighter outer parts), a marker for oligodendrocyte precursor cells.
Our results suggest that incubation of stem cells with the right choice of sphingolipids does not only eliminate teratoma-forming cells but may also sustain cell polarity and promote differentiation. The strategy of making SENSe may thus have broader implications for designing protocols that increase the performance of stem cells. This may include enhancement of adult stem cells used for transplantation, e.g. bone marrow stem cells, but also endogenous progenitor cells. Most recently, it has been shown that S1P and FTY720 promote survival and differentiation of primary cultured oligodendrocyte precursors $[183,184]$. FTY720 is already used for clinical trials to treat multiple sclerosis, mainly because of its immuno- suppressing activity [185-189]. Based on these studies, it is reasonable to speculate that FTY720 may also spur remyelination because it promotes survival and differentiation of endogenous oligodendrocyte precursors [183]. This example shows that sphingolipids will have a promising future as important components for the design of novel stem cell therapies and treatment of neurodegenerative disorders.

\section{Acknowledgement}

This work was supported by NIH grant R01NS046835. 


\section{References}

1 Bieberich E: Integration of glycosphingolipid metabolism and cell-fate decisions in cancer and stem cells: review and hypothesis. Glycoconj J 2004;21:315-327.

-2 Wang G, Silva J, Krishnamurthy K, Tran E, Condie BG, Bieberich E: Direct binding to ceramide activates protein kinase Czeta before the formation of a pro-apoptotic complex with PAR-4 in differentiating stem cells. J Biol Chem 2005;280:26415-26424.

>3 Krishnamurthy K, Wang G, Silva J, Condie BG, Bieberich E: Ceramide regulates atypical PKC $\{$ zeta $\} /\{$ lambda $\}$-mediated cell polarity in primitive ectoderm cells: a novel function of sphingolipids in morphogenesis. J Biol Chem 2007;282:3379-3390.

4 Bieberich E, MacKinnon S, Silva J, Noggle S, Condie BG: Regulation of cell death in mitotic neural progenitor cells by asymmetric distribution of prostate apoptosis response 4 (PAR-4) and simultaneous elevation of endogenous ceramide. J Cell Biol 2003;162: 469-479.

5 Bieberich E, Silva J, Wang G, Krishnamurthy $\mathrm{K}$, Condie BG: Selective apoptosis of pluripotent mouse and human stem cells by novel ceramide analogues prevents teratoma formation and enriches for neural precursors in ES cell-derived neural transplants. J Cell Biol 2004; 167:723-734.

6 Wang G, Silva J, Krishnamurthy K, Bieberich $\mathrm{E}$ : A novel isoform of prostate apoptosis response 4 (PAR-4) that co-distributes with $\mathrm{F}$-actin and prevents apoptosis in neural stem cells. Apoptosis 2006;11:315-325.

7 Bieberich E, Hu B, Silva J, MacKinnon S, Yu RK, Fillmore H, et al: Synthesis and characterization of novel ceramide analogs for induction of apoptosis in human cancer cells. Cancer Lett 2002;181:55-64.

$\checkmark 8$ Bieberich E, Kawaguchi T, Yu RK: N-acylated serinol is a novel ceramide mimic inducing apoptosis in neuroblastoma cells. J Biol Chem 2000;275:177-181.

$\checkmark 9$ Hentze H, Graichen R, Colman A: Cell therapy and the safety of embryonic stem cellderived grafts. Trends Biotechnol 2007;25: 24-32.

10 Waeber C, Blondeau N, Salomone S: Vascular sphingosine-1-phosphate S1P1 and S1P3 receptors. Drug News Perspect 2004;17:365382 .

-11 Zhang J, Honbo N, Goetzl EJ, Chatterjee K, Karliner JS, Gray MO: Signals from type 1 sphingosine 1-phosphate receptors enhance adult mouse cardiac myocyte survival during hypoxia. Am J Physiol Heart Circ Physiol 2007;293:H3150-H3158. Epub 2007 Aug 31.

-12 Young N, Van Brocklyn JR: Signal transduction of sphingosine-1-phosphate G proteincoupled receptors. Scientif World J 2006;6: 946-966.
13 Watterson K, Sankala H, Milstien S, Spiegel S: Pleiotropic actions of sphingosine-1-phosphate. Prog Lipid Res 2003;42:344-357.

14 Toman RE, Spiegel S: Lysophospholipid receptors in the nervous system. Neurochem Res 2002;27:619-627.

15 Houssa B, van Blitterswijk WJ: Specificity of cysteine-rich domains in diacylglycerol kinases and protein kinases C. Biochem J 1998; 331:677-679.

16 Colon-Gonzalez F, Kazanietz MG: C1 domains exposed: from diacylglycerol binding to protein-protein interactions. Biochim Biophys Acta 2006;1761:827-837.

17 Giorgione J, Hysell M, Harvey DF, Newton AC: Contribution of the $\mathrm{C} 1 \mathrm{~A}$ and $\mathrm{C} 1 \mathrm{~B}$ domains to the membrane interaction of protein kinase C. Biochemistry 2003;42:1119411202.

18 Feng H, Ren M, Chen L, Rubin CS: Properties, regulation and in vivo functions of a novel protein kinase D: C. elegans DKF-2 links diacylglycerol second messenger to the regulation of stress responses and lifespan. J Biol Chem 2007;282:31273-31288.

19 Wang QJ, Fang TW, Yang D, Lewin NE, Van Lint J, Marquez VE, et al: Ligand structureactivity requirements and phospholipid dependence for the binding of phorbol esters to protein kinase D. Mol Pharmacol 2003;64: 1342-1348.

20 Kubiseski TJ, Chook YM, Parris WE, Rozakis-Adcock M, Pawson T: High affinity binding of the pleckstrin homology domain of mSos1 to phosphatidylinositol (4,5)-bisphosphate. J Biol Chem 1997;272:1799-1804.

21 Snook CF, Jones JA, Hannun YA: Sphingolipid-binding proteins. Biochim Biophys Acta 2006;1761:927-946.

22 Chalfant CE, Szulc Z, Roddy P, Bielawska A, Hannun YA: The structural requirements for ceramide activation of serine-threonine protein phosphatases. J Lipid Res 2004;45: 496-506.

23 Dobrowsky RT, Hannun YA: Ceramide stimulates a cytosolic protein phosphatase. J Biol Chem 1992;267:5048-5051.

24 Lozano J, Berra E, Municio MM, Diaz-Meco MT, Dominguez I, Sanz L, et al: Protein kinase C zeta isoform is critical for kappa Bdependent promoter activation by sphingomyelinase. J Biol Chem 1994;269:1920019202.

25 Muller G, Ayoub M, Storz P, Rennecke J, Fabbro D, Pfizenmaier K: PKC zeta is a molecular switch in signal transduction of TNF-alpha, bifunctionally regulated by ceramide and arachidonic acid. Embo J 1995;14:19611969.

26 Fox TE, Houck KL, O’Neill SM, Nagarajan M, Stover TC, Pomianowski PT, et al: Ceramide recruits and activates PKCzeta within structured membrane microdomains. J Biol Chem 2007;282:12450-12457.
27 Bourbon NA, Yun J, Kester M: Ceramide directly activates protein kinase $\mathrm{C}$ zeta to regulate a stress-activated protein kinase signaling complex. J Biol Chem 2000;275: 35617-35623.

$>28$ Wang YM, Seibenhener ML, Vandenplas ML, Wooten MW: Atypical PKC zeta is activated by ceramide, resulting in coactivation of NF-kappaB/JNK kinase and cell survival. J Neurosci Res 1999;55:293-302.

29 Liu J, Mathias S, Yang Z, Kolesnick RN: Renaturation and tumor necrosis factor-alpha stimulation of a $97-\mathrm{kDa}$ ceramide-activated protein kinase. J Biol Chem 1994;269:30473052.

30 Mathias S, Dressler KA, Kolesnick RN: Characterization of a ceramide-activated protein kinase: stimulation by tumor necrosis factor alpha. Proc Natl Acad Sci USA 1991;88:10009-10013.

31 Sugiura M, Kono K, Liu H, Shimizugawa T, Minekura H, Spiegel S, et al: Ceramide kinase, a novel lipid kinase: molecular cloning and functional characterization. J Biol Chem 2002;277:23294-23300.

32 Stahelin RV, Subramanian P, Vora M, Cho W, Chalfant CE: Ceramide-1-phosphate binds group IVA cytosolic phospholipase a2 via a novel site in the $\mathrm{C} 2$ domain. J Biol Chem 2007;282:20467-20474.

33 Pettus BJ, Bielawska A, Subramanian P, Wijesinghe DS, Maceyka M, Leslie CC, et al: Ceramide 1-phosphate is a direct activator of cytosolic phospholipase A2. J Biol Chem 2004;279:11320-11326.

34 Takuwa Y, Okamoto H, Takuwa N, Gonda K, Sugimoto N, Sakurada S: Subtype-specific, differential activities of the EDG family receptors for sphingosine-1-phosphate, a novel lysophospholipid mediator. Mol Cell Endocrinol 2001;177:3-11.

35 Sanchez T, Hla T: Structural and functional characteristics of S1P receptors. J Cell Biochem 2004;92:913-922.

36 Taha TA, Argraves KM, Obeid LM: Sphingosine-1-phosphate receptors: receptor specificity versus functional redundancy. Biochim Biophys Acta 2004;1682:48-55.

37 Spiegel S, Milstien S: Sphingosine-1-phosphate: an enigmatic signalling lipid. Nat Rev Mol Cell Biol 2003;4:397-407.

$\checkmark 38$ Galadari S, Kishikawa K, Kamibayashi C, Mumby MC, Hannun YA: Purification and characterization of ceramide-activated protein phosphatases. Biochemistry 1998;37: 11232-11238

39 Ohanian J, Ohanian V: Sphingolipids in mammalian cell signalling. Cell Mol Life Sci 2001;58:2053-2068.

40 van Blitterswijk WJ: Hypothesis: ceramide conditionally activates atypical protein $\mathrm{ki}$ nases C, Raf-1 and KSR through binding to their cysteine-rich domains. Biochem J 1998; 331:679-680. 
41 van Blitterswijk WJ, van der Luit AH, Veldman RJ, Verheij M, Borst J: Ceramide: second messenger or modulator of membrane structure and dynamics? Biochem J 2003;369: 199-211.

-42 Kajimoto T, Shirai Y, Sakai N, Yamamoto T, Matsuzaki H, Kikkawa U, et al: Ceramideinduced apoptosis by translocation, phosphorylation and activation of protein kinase Cdelta at Golgi complex. J Biol Chem 2004; 279:12668-12676.

-43 Kashiwagi K, Shirai Y, Kuriyama M, Sakai N, Saito N: Importance of C1B domain for lipid messenger-induced targeting of protein kinase C. J Biol Chem 2002;277:18037-18045.

44 Chalfant CE, Rathman K, Pinkerman RL, Wood RE, Obeid LM, Ogretmen B, et al: De novo ceramide regulates the alternative splicing of caspase 9 and Bcl-x in A549 lung adenocarcinoma cells. Dependence on protein phosphatase-1. J Biol Chem 2002;277: 12587-12595.

-45 Ruvolo PP: Intracellular signal transduction pathways activated by ceramide and its metabolites. Pharmacol Res 2003;47:383-392.

-46 Yan F, Polk DB: Kinase suppressor of ras is necessary for tumor necrosis factor alpha activation of extracellular signal-regulated kinase/mitogen-activated protein kinase in intestinal epithelial cells. Cancer Res 2001;61: 963-969.

-47 Zhang Y, Yao B, Delikat S, Bayoumy S, Lin $\mathrm{XH}$, Basu S, et al: Kinase suppressor of Ras is ceramide-activated protein kinase. Cell 1997;89:63-72.

48 Gulbins E, Grassme H: Ceramide and cell death receptor clustering. Biochim Biophys Acta 2002; 1585:139-145.

49 Megha, Sawatzki P, Kolter T, Bittman R, London E: Effect of ceramide $\mathrm{N}$-acyl chain and polar headgroup structure on the properties of ordered lipid domains (lipid rafts). Biochim Biophys Acta 2007; 1768:2205-2212.

50 Chiantia S, Kahya N, Schwille P: Raft domain reorganization driven by short- and long-chain ceramide: a combined AFM and FCS study. Langmuir 2007;23:7659-7665.

51 Johnston I, Johnston LJ: Ceramide promotes restructuring of model raft membranes. Langmuir 2006;22:11284-11289.

-52 Cremesti A, Paris F, Grassme H, Holler N, Tschopp J, Fuks Z, et al: Ceramide enables fas to cap and kill. J Biol Chem 2001;276: 23954-23961.

53 Grassme H, Cremesti A, Kolesnick R, Gulbins E: Ceramide-mediated clustering is required for CD95-DISC formation. Oncogene 2003;22:5457-5470.

54 Gulbins E, Dreschers S, Wilker B, Grassme $\mathrm{H}$ : Ceramide, membrane rafts and infections. J Mol Med 2004;82:357-363.

-55 Gulbins E, Coggeshall KM, Brenner B, Schlottmann K, Linderkamp O, Lang F: Fasinduced apoptosis is mediated by activation of a Ras and Rac protein-regulated signaling pathway. J Biol Chem 1996;271:2638926394.
56 Gulbins E, Kolesnick R: Raft ceramide in molecular medicine. Oncogene 2003;22: 7070-7077.

57 Dumitru CA, Carpinteiro A, Trarbach T, Hengge UR, Gulbins E: Doxorubicin enhances TRAIL-induced cell death via ceramide-enriched membrane platforms Apoptosis 2007;12:1533-1541.

58 Bollinger CR, Teichgraber V, Gulbins E: Ceramide-enriched membrane domains. Biochim Biophys Acta 2005;1746:284-294.

59 Fernandez-Veledo S, Hernandez R, Teruel T, Mas JA, Ros M, Lorenzo M: Ceramide mediates TNF-alpha-induced insulin resistance on GLUT4 gene expression in brown adipocytes. Arch Physiol Biochem 2006;112:1322 .

60 Hanna AN, Berthiaume LG, Kikuchi Y, Begg D, Bourgoin S, Brindley DN: Tumor necrosis factor-alpha induces stress fiber formation through ceramide production: role of sphingosine kinase. Mol Biol Cell 2001;12:36183630 .

61 Llacuna L, Mari M, Garcia-Ruiz C, Fernandez-Checa JC, Morales A: Critical role of acidic sphingomyelinase in murine hepatic ischemia-reperfusion injury. Hepatology 2006;44:561-572.

62 Clarke CJ, Snook CF, Tani M, Matmati N, Marchesini N, Hannun YA: The extended family of neutral sphingomyelinases. Biochemistry 2006;45:11247-11256.

63 Barker PA: p75NTR: A study in contrasts. Cell Death Differ 1998;5:346-356.

-64 Brann AB, Scott R, Neuberger Y, Abulafia D Boldin S, Fainzilber M, et al: Ceramide signaling downstream of the p75 neurotrophin receptor mediates the effects of nerve growth factor on outgrowth of cultured hippocampal neurons. J Neurosci 1999;19:8199-8206.

65 Roux PP, Barker PA: Neurotrophin signaling through the p75 neurotrophin receptor. Prog Neurobiol 2002;67:203-233.

66 Barker PA: p75NTR is positively promiscuous: novel partners and new insights. Neuron 2004;42:529-533.

67 Barker PA: High affinity not in the vicinity? Neuron 2007;53:1-4.

68 Costantini C, Weindruch R, Della Valle G, Puglielli L: A TrkA-to-p75NTR molecular switch activates amyloid beta-peptide generation during aging. Biochem J 2005;391: 59-67.

69 Costantini C, Scrable H, Puglielli L: An aging pathway controls the TrkA to p75NTR receptor switch and amyloid beta-peptide generation. Embo J 2006;25:1997-2006.

70 Yaar M, Zhai S, Pilch PF, Doyle SM, Eisenhauer PB, Fine RE, et al: Binding of beta-amyloid to the p75 neurotrophin receptor induces apoptosis. A possible mechanism for Alzheimer's disease. J Clin Invest 1997;100: 2333-2340.

71 Kuner P, Hertel C: NGF induces apoptosis in a human neuroblastoma cell line expressing the neurotrophin receptor p75NTR. J Neurosci Res 1998;54:465-474.
72 Naumann T, Casademunt E, Hollerbach E, Hofmann J, Dechant G, Frotscher M, et al: Complete deletion of the neurotrophin receptor p75NTR leads to long-lasting increases in the number of basal forebrain cholinergic neurons. J Neurosci 2002;22:2409-2418.

73 Dawbarn D, Allen SJ: Neurotrophins and neurodegeneration. Neuropathol Appl Neurobiol 2003;29:211-230.

74 Counts SE, Mufson EJ: The role of nerve growth factor receptors in cholinergic basal forebrain degeneration in prodromal $\mathrm{Alz}$ heimer disease. J Neuropathol Exp Neurol 2005;64:263-272.

75 Coulson EJ: Does the p75 neurotrophin receptor mediate Abeta-induced toxicity in Alzheimer's disease? J Neurochem 2006;98: 654-660.

76 Hatchett CS, Tyler S, Armstrong D, Dawbarn D, Allen SJ: Familial Alzheimer's disease presenilin 1 mutation $\mathrm{M} 146 \mathrm{~V}$ increases gamma secretase cutting of p75NTR in vitro. Brain Res 2007;1147:248-255.

77 Niederhauser O, Mangold M, Schubenel R, Kusznir EA, Schmidt D, Hertel C: NGF ligand alters NGF signaling via p75(NTR) and trkA. J Neurosci Res 2000;61:263-272.

78 Diolaiti D, Bernardoni R, Trazzi S, Papa A, Porro A, Bono F, et al: Functional cooperation between TrkA and p75(NTR) accelerates neuronal differentiation by increased transcription of GAP-43 and p21(CIP/WAF) genes via ERK1/2 and AP-1 activities. Exp Cell Res 2007;313:2980-2992.

79 Micera A, Lambiase A, Stampachiacchiere B, Bonini S, Bonini S, Levi-Schaffer F: Nerve growth factor and tissue repair remodeling: trkA(NGFR) and p75(NTR), two receptors one fate. Cytokine Growth Factor Rev 2007; 18:245-256.

$>80$ Wehrman T, He X, Raab B, Dukipatti A, Blau H, Garcia KC: Structural and mechanistic insights into nerve growth factor interactions with the TrkA and p75 receptors. Neuron 2007;53:25-38.

81 Verdi JM, Birren SJ, Ibanez CF, Persson H, Kaplan DR, Benedetti M, et al: p75LNGFR regulates Trk signal transduction and NGFinduced neuronal differentiation in $\mathrm{MAH}$ cells. Neuron 1994;12:733-745.

82 Heumann R: Neurotrophin signalling. Curr Opin Neurobiol 1994;4:668-679.

$>83$ Chao MV, Hempstead BL: p75 and Trk: a two-receptor system. Trends Neurosci 1995; 18:321-326.

$>84$ Casaccia-Bonnefil P, Carter BD, Dobrowsky RT, Chao MV: Death of oligodendrocytes mediated by the interaction of nerve growth factor with its receptor p75. Nature 1996;383: 716-719.

85 Greene LA, Kaplan DR: Early events in neurotrophin signalling via Trk and p75 receptors. Curr Opin Neurobiol 1995;5:579-587. 
86 Culmsee C, Gerling N, Lehmann M, Nikolova-Karakashian M, Prehn JH, Mattson MP, et al: Nerve growth factor survival signaling in cultured hippocampal neurons is mediated through TrkA and requires the common neurotrophin receptor P75. Neuroscience 2002;115:1089-1108.

87 Plo I, Bono F, Bezombes C, Alam A, Bruno A, Laurent G: Nerve growth factor-induced protein kinase $\mathrm{C}$ stimulation contributes to TrkA-dependent inhibition of p75 neurotrophin receptor sphingolipid signaling. J Neurosci Res 2004;77:465-474.

88 Colombaioni L, Garcia-Gil M: Sphingolipid metabolites in neural signalling and function. Brain Res Brain Res Rev 2004;46:328355.

89 Ji L, Zhang G, Uematsu S, Akahori Y, Hirabayashi Y: Induction of apoptotic DNA fragmentation and cell death by natural ceramide. FEBS Lett 1995;358:211-214.

90 Brugg B, Michel PP, Agid Y, Ruberg M: Ceramide induces apoptosis in cultured mesencephalic neurons. J Neurochem 1996;66: 733-739.

91 Chalfant CE, Kishikawa K, Mumby MC, Kamibayashi C, Bielawska A, Hannun YA: Long chain ceramides activate protein phosphatase- 1 and protein phosphatase-2A: activation is stereospecific and regulated by phosphatidic acid. J Biol Chem 1999;274: 20313-20317.

92 Irie F, Hirabayashi Y: Application of exogenous ceramide to cultured rat spinal motoneurons promotes survival or death by regulation of apoptosis depending on its concentrations. J Neurosci Res 1998;54:475485.

93 Sot J, Bagatolli LA, Goni FM, Alonso A: Detergent-resistant, ceramide-enriched domains in sphingomyelin/ceramide bilayers. Biophys J 2006;90:903-914.

94 Cowart LA, Szulc Z, Bielawska A, Hannun YA: Structural determinants of sphingolipid recognition by commercially available anticeramide antibodies. J Lipid Res 2002;43: 2042-2048.

-95 Krishnamurthy K, Dasgupta S, Bieberich E: Development and characterization of a novel anti-ceramide antibody. J Lipid Res 2007;48: 968-975.

96 Merrill AH Jr, Wang E: Enzymes of ceramide biosynthesis. Methods Enzymol 1992;209: 427-437.

-97 Perry RJ, Ridgway ND: Molecular mechanisms and regulation of ceramide transport. Biochim Biophys Acta 2005;1734:220-234.

-98 Bionda C, Portoukalian J, Schmitt D, Rodriguez-Lafrasse C, Ardail D: Subcellular compartmentalization of ceramide metabolism: MAM (mitochondria-associated membrane) and/or mitochondria? Biochem J 2004;382: 527-533.
99 Sandhoff K, Kolter T: Biosynthesis and degradation of mammalian glycosphingolipids. Phil Trans R Soc Lond [B] 2003;358: 847-861.

100 Kumagai K, Yasuda S, Okemoto K, Nishijima M, Kobayashi S, Hanada K: CERT mediates intermembrane transfer of various molecular species of ceramides. J Biol Chem 2005;280:6488-6495.

101 Decaudin D, Marzo I, Brenner C, Kroemer G: Mitochondria in chemotherapy-induced apoptosis: a prospective novel target of cancer therapy (review). Int J Oncol 1998;12: 141-152.

102 Anishkin A, Sukharev S, Colombini M: Searching for the molecular arrangement of transmembrane ceramide channels. Biophys J 2006;90:2414-2426.

103 Ledeen RW, Wu G: Sphingolipids of the nucleus and their role in nuclear signaling. Biochim Biophys Acta 2006;1761:588-598.

104 Albi E, Cataldi S, Bartoccini E, Magni MV Marini F, Mazzoni F, et al: Nuclear sphingomyelin pathway in serum deprivationinduced apoptosis of embryonic hippocampal cells. J Cell Physiol 2006;206: 189-195.

105 Sillence DJ: Apoptosis and signalling in acid sphingomyelinase deficient cells. BMC Cell Biol 2001;2:24.

106 Tani M, Hannun YA: Analysis of membrane topology of neutral sphingomyelinase 2. FEBS Lett 2007;581:1323-1328.

107 Mitsutake S, Igarashi Y: Transbilayer movement of ceramide in the plasma membrane of live cells. Biochem Biophys Res Commun 2007;359:622-627.

108 Tepper AD, Ruurs P, Wiedmer T, Sims PJ, Borst J, van Blitterswijk WJ: Sphingomyelin hydrolysis to ceramide during the execution phase of apoptosis results from phospholipid scrambling and alters cell-surface morphology. J Cell Biol 2000;150:155-164.

109 Lang KS, Lang PA, Bauer C, Duranton C, Wieder T, Huber SM, et al: Mechanisms of suicidal erythrocyte death. Cell Physiol Biochem 2005;15:195-202.

110 Yu A, McMaster CR, Byers DM, Ridgway ND, Cook HW: Resistance to UV-induced apoptosis in Chinese-hamster ovary cells overexpressing phosphatidylserine synthases. Biochem J 2004;381:609-618.

111 Romsicki Y, Sharom FJ: Phospholipid flippase activity of the reconstituted P-glycoprotein multidrug transporter. Biochemistry 2001;40:6937-6947.

112 Goswami R, Singh D, Phillips G, Kilkus J, Dawson G: Ceramide regulation of the tumor suppressor phosphatase PTEN in rafts isolated from neurotumor cell lines. J Neurosci Res 2005;81:541-550.

113 Bieberich E, MacKinnon S, Silva J, Yu RK: Regulation of apoptosis during neuronal differentiation by ceramide and b-series complex gangliosides. J Biol Chem 2001; 276:44396-44404.
114 Rankin CA, Sun Q, Gamblin TC: Tau phosphorylation by GSK-3beta promotes tangle-like filament morphology. Mol Neurodegener 2007;2:12.

115 Ikeda S, Kishida M, Matsuura Y, Usui H, Kikuchi A: GSK-3beta-dependent phosphorylation of adenomatous polyposis coli gene product can be modulated by betacatenin and protein phosphatase $2 \mathrm{~A}$ complexed with Axin. Oncogene 2000;19:537545.

116 Etienne-Manneville S, Hall A: Cdc42 regulates GSK-3beta and adenomatous polyposis coli to control cell polarity. Nature 2003; 421:753-756.

117 van Noort M, Meeldijk J, van der Zee R, Destree O, Clevers H: Wnt signaling controls the phosphorylation status of betacatenin. J Biol Chem 2002;277:1790117905.

118 Gartner A, Huang X, Hall A: Neuronal polarity is regulated by glycogen synthase kinase-3 (GSK-3beta) independently of Akt/ PKB serine phosphorylation. J Cell Sci 2006;119:3927-3934.

119 Takashima A: GSK-3 is essential in the pathogenesis of Alzheimer's disease. J Alzheimers Dis 2006;9(suppl 3):309-317.

120 Wang JZ, Grundke-Iqbal I, Iqbal K: Kinases and phosphatases and tau sites involved in Alzheimer neurofibrillary degeneration. Eur J Neurosci 2007;25:59-68.

121 Leclerc S, Garnier M, Hoessel R, Marko D, Bibb JA, Snyder GL, et al: Indirubins inhibit glycogen synthase kinase- 3 beta and CDK5/p25, two protein kinases involved in abnormal tau phosphorylation in Alzheimer's disease. A property common to most cyclin-dependent kinase inhibitors? J Biol Chem 2001;276:251-260.

122 Schlessinger K, McManus EJ, Hall A: Cdc42 and noncanonical Wnt signal transduction pathways cooperate to promote cell polarity. J Cell Biol 2007;178:355-361.

123 Liu GP, Zhang Y, Yao XQ, Zhang CE, Fang J, Wang Q, et al: Activation of glycogen synthase kinase-3 inhibits protein phosphatase-2A and the underlying mechanisms. Neurobiol Aging 2007. Epub ahead of print.

124 Lin CF, Chen CL, Chiang CW, Jan MS, Huang WC, Lin YS: GSK-3beta acts downstream of PP2A and the PI 3-kinase-Akt pathway, and upstream of caspase-2 in ceramide-induced mitochondrial apoptosis. J Cell Sci 2007;120:2935-2943.

125 Sells SF, Wood DP Jr, Joshi-Barve SS, Muthukumar S, Jacob RJ, Crist SA, et al: Commonality of the gene programs induced by effectors of apoptosis in androgen-dependent and -independent prostate cells. Cell Growth Differ 1994:5:457-466. 
-126 Diaz-Meco MT, Municio MM, Frutos S, Sanchez P, Lozano J, Sanz L, et al: The product of par-4, a gene induced during apoptosis, interacts selectively with the atypical isoforms of protein kinase C. Cell 1996;86: 777-786.

127 Johnstone RW, Wang J, Tommerup N, Vissing $\mathrm{H}$, Roberts T, Shi Y: Ciao 1 is a novel WD40 protein that interacts with the tumor suppressor protein WT1. J Biol Chem 1998;273:10880-10887.

- 128 Jiang H, Guo W, Liang X, Rao Y: Both the establishment and the maintenance of neuronal polarity require active mechanisms: critical roles of GSK-3beta and its upstream regulators. Cell 2005;120:123-135.

-129 Duan W, Rangnekar VM, Mattson MP: Prostate apoptosis response-4 production in synaptic compartments following apoptotic and excitotoxic insults: evidence for a pivotal role in mitochondrial dysfunction and neuronal degeneration. J Neurochem 1999;72:2312-2322.

-130 Mattson MP, Culmsee C, Yu Z, Camandola S: Roles of nuclear factor kappaB in neuronal survival and plasticity. J Neurochem 2000;74:443-456.

-131 Mattson MP, Meffert MK: Roles for NFkappaB in nerve cell survival, plasticity, and disease. Cell Death Differ 2006;13: 852-860.

-132 Mattson MP, Duan W, Chan SL, Camandola S: Par-4: an emerging pivotal player in neuronal apoptosis and neurodegenerative disorders. J Mol Neurosci 1999;13:17-30.

-133 Guo Q, Xie J, Du H: Par-4 induces cholinergic hypoactivity by suppressing ChAT protein synthesis and inhibiting NGF-inducibility of ChAT activity. Brain Res 2000; 874:221-232.

134 Xie J, Guo Q: Par-4 inhibits choline uptake by interacting with $\mathrm{CHT} 1$ and reducing its incorporation on the plasma membrane. J Biol Chem 2004;279:28266-28275.

-135 Mattson MP: Apoptotic and anti-apoptotic synaptic signaling mechanisms. Brain Pathol 2000;10:300-312.

136 Vetterkind S, Illenberger S, Kubicek J, Boosen M, Appel S, Naim HY, et al: Binding of Par-4 to the actin cytoskeleton is essential for Par-4/Dlk-mediated apoptosis. Exp Cell Res 2005;305:392-408.

-137 Spiegel S, Cuvillier O, Edsall LC, Kohama T, Menzeleev R, Olah Z, et al: Sphingosine1-phosphate in cell growth and cell death. Ann NY Acad Sci 1998;845:11-18.

-138 Mizugishi K, Yamashita T, Olivera A, Miller GF, Spiegel S, Proia RL: Essential role for sphingosine kinases in neural and vascular development. Mol Cell Biol 2005;25:1111311121.

-139 Alemany R, van Koppen CJ, Danneberg K, Ter Braak M, Meyer Zu Heringdorf D: Regulation and functional roles of sphingosine kinases. Naunyn Schmiedebergs Arch Pharmacol 2007;374:413-428.
140 Hait NC, Oskeritzian CA, Paugh SW, Milstien S, Spiegel S: Sphingosine kinases, sphingosine 1-phosphate, apoptosis and diseases. Biochim Biophys Acta 2006;1758: 2016-2026.

141 Huwiler A, Pfeilschifter J: Altering the sphingosine-1-phosphate/ceramide balance: a promising approach for tumor therapy. Curr Pharm Des 2006;12:4625-4635.

142 Spiegel S, Milstien S: Functions of the multifaceted family of sphingosine kinases and some close relatives. J Biol Chem 2007;282: 2125-2129.

143 Chalfant CE, Spiegel S: Sphingosine 1phosphate and ceramide 1-phosphate: expanding roles in cell signaling. J Cell Sci 2005;118:4605-4612.

144 Maceyka M, Sankala H, Hait NC, Le Stunff H, Liu H, Toman R, et al: SphK1 and SphK2, sphingosine kinase isoenzymes with opposing functions in sphingolipid metabolism. J Biol Chem 2005;280:37118-37129.

145 Sanna MG, Liao J, Jo E, Alfonso C, Ahn MY, Peterson MS, et al: Sphingosine 1-phosphate $(\mathrm{S} 1 \mathrm{P})$ receptor subtypes S1P1 and S1P3, respectively, regulate lymphocyte recirculation and heart rate. J Biol Chem 2004;279:13839-13848.

146 Hla T, Lee MJ, Ancellin N, Thangada S, Liu $\mathrm{CH}$, Kluk M, et al: Sphingosine-1-phosphate signaling via the EDG-1 family of Gprotein-coupled receptors. Ann NY Acad Sci 2000;905:16-24.

147 Lee MJ, Evans M, Hla T: The inducible G protein-coupled receptor edg-1 signals via the $\mathrm{G}(\mathrm{i}) /$ mitogen-activated protein kinase pathway. J Biol Chem 1996;271:1127211279.

148 Le Stunff H, Galve-Roperh I, Peterson C, Milstien S, Spiegel S: Sphingosine-1-phosphate phosphohydrolase in regulation of sphingolipid metabolism and apoptosis. J Cell Biol 2002;158:1039-1049.

149 Rakhit S, Conway AM, Tate R, Bower T, Pyne NJ, Pyne S: Sphingosine 1-phosphate stimulation of the $\mathrm{p} 42 / \mathrm{p} 44$ mitogen-activated protein kinase pathway in airway smooth muscle. Role of endothelial differentiation gene 1, c-Src tyrosine kinase and phosphoinositide 3-kinase. Biochem J 1999; 338:643-649.

150 Hsieh HL, Wu CB, Sun CC, Liao CH, Lau YT, Yang CM: Sphingosine-1-phosphate induces COX-2 expression via PI3K/Akt and p42/p44 MAPK pathways in rat vascular smooth muscle cells. J Cell Physiol 2006; 207:757-766.

151 Harada J, Foley M, Moskowitz MA, Waeber C: Sphingosine-1-phosphate induces proliferation and morphological changes of neural progenitor cells. J Neurochem 2004; 88:1026-1039.

152 Gonzalez-Cabrera PJ, Hla T, Rosen H: Mapping pathways downstream of S1P1 by differential chemical perturbation and proteomics. J Biol Chem 2007;282:7254-7264.
153 Oh JE, So KS, Lim SJ, Kim MY: Induction of apoptotic cell death by a ceramide analog in PC-3 prostate cancer cells. Arch Pharm Res 2006;29:1140-1146.

154 Stoica BA, Movsesyan VA, Lea PMt, Faden AI: Ceramide-induced neuronal apoptosis is associated with dephosphorylation of Akt, BAD, FKHR, GSK-3beta, and induction of the mitochondrial-dependent intrinsic caspase pathway. Mol Cell Neurosci 2003;22:365-382.

155 Basu S, Bayoumy S, Zhang Y, Lozano J, Kolesnick R: BAD enables ceramide to signal apoptosis via Ras and Raf-1. J Biol Chem 1998;273:30419-30426.

156 Jarvis WD, Fornari FA Jr, Auer KL, Freemerman AJ, Szabo E, Birrer MJ, et al: Coordinate regulation of stress- and mitogenactivated protein kinases in the apoptotic actions of ceramide and sphingosine. Mol Pharmacol 1997;52:935-947.

-157 Nussbaum J, Minami E, Laflamme MA, Virag JA, Ware CB, Masino A, et al: Transplantation of undifferentiated murine embryonic stem cells in the heart: teratoma formation and immune response. FASEB J 2007;21:1345-1357.

158 Arnhold S, Klein H, Semkova I, Addicks K, Schraermeyer U: Neurally selected embryonic stem cells induce tumor formation after long-term survival following engraftment into the subretinal space. Invest Ophthalmol Vis Sci 2004;45:4251-4255.

159 Fujikawa T, Oh SH, Pi L, Hatch HM, Shupe T, Petersen BE: Teratoma formation leads to failure of treatment for type I diabetes using embryonic stem cell-derived insulin-producing cells. Am J Pathol 2005;166:17811791.

160 Swijnenburg RJ, Tanaka M, Vogel H, Baker J, Kofidis T, Gunawan F, et al: Embryonic stem cell immunogenicity increases upon differentiation after transplantation into ischemic myocardium. Circulation 2005; 112(suppl 9):1166-1172.

161 Teramoto K, Hara Y, Kumashiro Y, Chinzei R, Tanaka Y, Shimizu-Saito K, et al: Teratoma formation and hepatocyte differentiation in mouse liver transplanted with mouse embryonic stem cell-derived embryoid bodies. Transplant Proc 2005;37: 285-286.

162 Vogel G: Cell biology. Ready or not? Human ES cells head toward the clinic. Science 2005;308:1534-1538.

163 Wakitani S, Takaoka K, Hattori T, Miyazawa N, Iwanaga T, Takeda S, et al: Embryonic stem cells injected into the mouse knee joint form teratomas and subsequently destroy the joint. Rheumatology (Oxford) 2003;42:162-165.

164 Yanai J, Doetchman T, Laufer N, Maslaton J, Mor-Yosef S, Safran A, et al: Embryonic cultures but not embryos transplanted to the mouse's brain grow rapidly without immunosuppression. Int J Neurosci 1995;81: 21-26. 
$>165$ Leor J, Gerecht-Nir S, Cohen S, Miller L, Holbova R, Ziskind A, et al: Human embryonic stem cell transplantation to repair the infarcted myocardium. Heart 2007;93: 1278-1284.

166 Asano T, Sasaki K, Kitano Y, Terao K, Hanazono Y: In vivo tumor formation from primate embryonic stem cells. Methods Mol Biol 2006;329:459-467.

167 Dihne M, Bernreuther C, Hagel C, Wesche KO, Schachner M: Embryonic stem cell-derived neuronally committed precursor cells with reduced teratoma formation after transplantation into the lesioned adult mouse brain. Stem Cells 2006;24:14581466.

- 168 Wernig M, Meissner A, Foreman R, Brambrink T, Ku M, Hochedlinger K, et al: In vitro reprogramming of fibroblasts into a pluripotent ES-cell-like state. Nature 2007; 448:318-324.

169 Fukuda H, Takahashi J, Watanabe K, Hayashi H, Morizane A, Koyanagi M, et al: Fluorescence-activated cell sorting-based purification of embryonic stem cell-derived neural precursors averts tumor formation after transplantation. Stem Cells 2006;24:763-771.

-170 Barraud P, Thompson L, Kirik D, Bjorklund A, Parmar M: Isolation and characterization of neural precursor cells from the Sox1-GFP reporter mouse. Eur J Neurosci 2005;22:1555-1569.

-171 Glaser T, Perez-Bouza A, Klein K, Brustle O: Generation of purified oligodendrocyte progenitors from embryonic stem cells. FASEB J 2005;19:112-114.
172 Lin T, Xiang Z, Cui L, Stallcup W, Reeves SA: New mouse oligodendrocyte precursor (mOP) cells for studies on oligodendrocyte maturation and function. J Neurosci Methods 2006;157:187-194.

173 Brustle O, Jones KN, Learish RD, Karram K, Choudhary K, Wiestler OD, et al: Embryonic stem cell-derived glial precursors: a source of myelinating transplants. Science 1999;285:754-756

174 Kim JH, Panchision D, Kittappa R, McKay R: Generating CNS neurons from embryonic, fetal, and adult stem cells. Methods Enzymol 2003;365:303-327.

175 Cai J, Wu Y, Mirua T, Pierce JL, Lucero MT, Albertine $\mathrm{KH}$, et al: Properties of a fetal multipotent neural stem cell (NEP cell). Dev Biol 2002;251:221-240.

176 Mujtaba T, Piper DR, Kalyani A, Groves AK, Lucero MT, Rao MS: Lineage-restricted neural precursors can be isolated from both the mouse neural tube and cultured ES cells. Dev Biol 1999;214:113-127.

177 Rao MS, Noble M, Mayer-Proschel M: A tripotential glial precursor cell is present in the developing spinal cord. Proc Natl Acad Sci USA 1998;95:3996-4001.

178 Rao MS, Mayer-Proschel M: Glial-restricted precursors are derived from multipotent neuroepithelial stem cells. Dev Biol 1997; 188:48-63.

179 Wilson HC, Onischke C, Raine CS: Human oligodendrocyte precursor cells in vitro: phenotypic analysis and differential response to growth factors. Glia 2003;44:153165.

- 180 Nishiyama A, Yang Z, Butt A: Astrocytes and NG2-glia: what's in a name? J Anat 2005;207:687-693.

181 Chang A, Nishiyama A, Peterson J, Prineas J, Trapp BD: NG2-positive oligodendrocyte progenitor cells in adult human brain and multiple sclerosis lesions. J Neurosci 2000; 20:6404-6412.
182 Lepore AC, Han SS, Tyler-Polsz CJ, Cai J, Rao MS, Fischer I: Differential fate of multipotent and lineage-restricted neural precursors following transplantation into the adult CNS. Neuron Glia Biol 2004;1:113126.

183 Coelho RP, Payne SG, Bittman R, Spiegel S, Sato-Bigbee C: The immunomodulator FTY720 has a direct cytoprotective effect in oligodendrocyte progenitors. J Pharmacol Exp Ther 2007;323:626-635.

184 Saini HS, Coelho RP, Goparaju SK, Jolly PS, Maceyka M, Spiegel S, et al: Novel role of sphingosine kinase 1 as a mediator of neurotrophin-3 action in oligodendrocyte progenitors. J Neurochem 2005;95:1298-1310.

185 Brinkmann V, Davis MD, Heise CE, Albert $\mathrm{R}$, Cottens S, Hof $\mathrm{R}$, et al: The immune modulator FTY720 targets sphingosine 1phosphate receptors. J Biol Chem 2002;277: 21453-21457.

186 Budde K, Schmouder RL, Brunkhorst R, Nashan B, Lucker PW, Mayer T, et al: First human trial of FTY720, a novel immunomodulator, in stable renal transplant patients. J Am Soc Nephrol 2002;13:10731083.

187 Davis MD, Clemens JJ, Macdonald TL, Lynch KR: Sphingosine 1-phosphate analogs as receptor antagonists. J Biol Chem 2005;280:9833-9841.

188 Aki FT, Kahan BD: FTY720: A new kid on the block for transplant immunosuppression. Expert Opin Biol Ther 2003;3:665681.

189 Napoli KL: The FTY720 story. Ther Drug Monit 2000;22:47-51. 